\title{
Isolated $d-f$ pairs in supramolecular complexes with tunable structural and electronic properties $\uparrow$
}

\author{
Claude Piguet, ${ }^{* a}$ Carine Edder, ${ }^{a}$ Stéphane Rigault, ${ }^{a}$ Gérald Bernardinelli, ${ }^{b}$ \\ Jean-Claude G. Bünzli ${ }^{c}$ and Gérard Hopfgartner ${ }^{d}$ \\ ${ }^{a}$ Department of Inorganic, Analytical and Applied Chemistry, University of Geneva, \\ 30 quai E. Ansermet, CH-1211 Geneva 4, Switzerland.E-mail: Claude.Piguet@chiam.unige.ch \\ ${ }^{b}$ Laboratory for X-Ray Crystallography, University of Geneva, 24 quai E. Ansermet, \\ CH-1211 Geneva 4, Switzerland \\ ${ }^{c}$ Institute of Inorganic and Analytical Chemistry, University of Lausanne, BCH 1402, \\ CH-1015 Lausanne, Switzerland \\ ${ }^{d}$ F. Hoffmann-La Roche Ltd, Pharmaceuticals Division, PRNS 68/142, CH-4070 Basle, \\ Switzerland
}

\section{Received 3rd May 2000, Accepted 7th August 2000 \\ First published as an Advance Article on the web 11th October 2000}

The use of predisposed segmental ligands in multicomponent self-assembly processes allows the preparation of triple-helical heterodimetallic $d-f$ complexes in which each pair of metal ions is isolated and protected from external interactions. The selection of the programmed heterodimetallic edifice within the 'dynamic virtual library' arising from the mixture of the reacting components relies on a judicious matching between the stereochemical preferences of the metal ions and the binding abilities of the receptors combined with a reliable characterisation of the

$\uparrow$ Presented as a Golden Jubilee Lecture at the 34th International Conference on Coordination Chemistry (ICCC34), University of Edinburgh, 9-14th July 2000.

\begin{abstract}
thermodynamic equilibria controlling the assembly process. Minor modifications of the receptors (donor groups, peripheral substituents) have considerable effects on formation of heterodimetallic d-f complexes $(\mathrm{HHH})-\left[\mathrm{LnM}(\mathrm{L})_{3}\right]$ $\{\mathrm{L}=$ bis[1-methyl-2-(2-pyridyl)benzimidazol-5-yl]methane derivative\} thus leading to successive improvements of the stability in aqueous solvent and to the fine tuning of structural and electronic properties. The implementation of specific light-converting properties, thermochromism, switchable magnetism and tunable dynamic behaviour are discussed together with the development of new paramagnetic NMR techniques for characterising lanthanide-containing dimetallic architectures in solution.
\end{abstract}

Claude Piguet obtained his PhD thesis with felicitations in 1989 (University of Geneva) in the field biomimetic copper-dioxygen complexes. After a postdoctoral period in the group of Prof. J.-M. Lehn, he collaborated as Maître-assistant with Prof. A. F. Williams and Prof. J.-C. G. Bünzli. In 1995 he received the Werner Medal of the New Swiss Chemical Society and the Werner grant. Lecturer at the University of Geneva (1995-1998), he was appointed full Professor of Inorganic Chemistry in 1999. His research interests and topics include the design of self-assembled supramolecular complexes with d-block and f-block metal ions, the preparation of lanthanidecontaining metallomesogens and the development of paramagnetic NMR.

Jean-Claude Bünzli earned his PhD degree at the Swiss Federal Institute of Technology (Lausanne) in 1971. He spent two years at the University of British Columbia (photoelectron spectroscopy) and one year at the Swiss Federal Institute of Technology in Zürich (physical organic chemistry) as a teaching postdoctoral fellow. Since 1980 he is acting as full professor at the University of Lausanne where he pursues a research program on the coordination and spectrochemistry of lanthanide ions, with particular interests in the relationship between structure and luminescent properties and in the design of supramolecular luminescent probes.

Carine Edder obtained her MS in Chemistry in 1997 (University of Geneva) and started a PhD in metallosupramolecular chemistry in the group of Prof. C. Piguet. Her current research concerns the synthesis and characterization of magnetically and optically active heterodimetallic $d-f$ complexes.

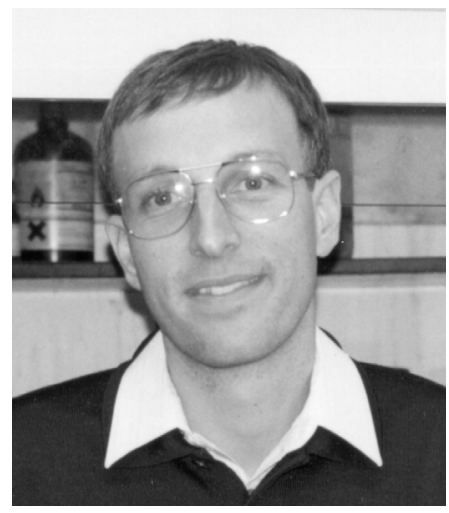

Claude Piguet

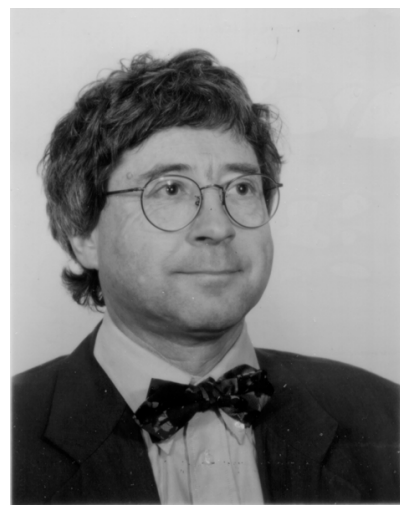

Jean-Claude G. Bünzli

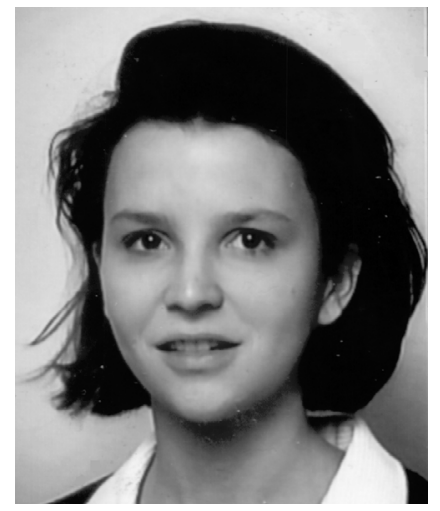

Carine Edder 


\section{Introduction}

Compared to the few reports describing heterodimetallic $\mathrm{f}-\mathrm{f}$ complexes, ${ }^{1}$ the synthesis of heteropolymetallic $\mathrm{d}-\mathrm{f}$ complexes is well documented because the two different metal ions display specific stereochemical preferences. ${ }^{2-8}$ As a result of the limited molecular information ${ }^{9}$ encoded in acyclic multidentate chelating ligands, poorly predictable oligomeric and polymeric architectures are usually characterised only in the solid state, ${ }^{3-5,8}$ although fascinating magnetically and optically active motifs have been recognised such as ladders, ${ }^{7,10}$ metallacrowns ${ }^{11}$ and clusters. ${ }^{8,12}$ Much effort has been focused on the preparation of heteropolymetallic edifices containing orbitally non-degenerate $\mathrm{Cu}^{\mathrm{II}}\left(\mathrm{d}^{9}, \mathrm{~S}=1 / 2\right)$ and $\mathrm{Gd}^{\mathrm{III}}\left(\mathrm{f}^{7}, \mathrm{~S}=7 / 2\right)$ in order to rationalise the weak magnetic exchange interactions between $\mathrm{d}$ - and f-block ions. Although polymetallic complexes significantly complicate the interpretation of magnetic data, the $\mathrm{Cu}-\mathrm{Gd}$ exchange processes systematically involve weak ferromagnetic couplings $\left(J_{\mathrm{ex}} \leq 15 \mathrm{~cm}^{-1}\right)$ resulting from the interaction of the groundstate configuration with the first excited charge-transfer configuration in which an unpaired electron of $\mathrm{Cu}^{\mathrm{II}}$ is transferred into the empty $5 \mathrm{~d}$ orbitals of $\mathrm{Gd}^{\mathrm{III}}$ 3,4 according to a mechanism first introduced by Goodenough in $1963 .{ }^{13}$ Recent advances in molecular recognition and metallosupramolecular assembly processes have led to the design of isolated $\mathrm{Cu}^{\mathrm{II}}-\mathrm{Gd}^{\mathrm{III}}$ pairs which confirm the theoretical basis of the magnetic exchange theory. ${ }^{3,5}$ These pure heterodimetallic systems open new perspectives for (i) the exploration of interactions between $\mathrm{f}$ - and d-block ions possessing first-order orbital momenta, ${ }^{5-8}$ (ii) the preparation of extended and organised heterotrimetallic $\mathrm{d}-\mathrm{f}-$ $\mathrm{d}^{14}$ and $\mathrm{f}-\mathrm{d}-\mathrm{f}^{15}$ architectures in the solid state and (iii) the detailed re-examination of the intimate mechanism proposed by Goodenough. ${ }^{6}$ However, the $\mathrm{d}-\mathrm{f}$ magnetic exchanges remain weak and operate only at low temperature because the degree of orbital overlap is small. Through-space multipolar mechanisms involving spectral overlaps overcome this limitation and efficient $\mathrm{d} \leftrightarrow \mathrm{f}$ energy transfers over long distances can be detected under standard conditions. ${ }^{16}$ For instance, the replace- ment of $\mathrm{Ca}^{\mathrm{II}}$ by $\mathrm{Ln}^{\mathrm{III}}$ (often $\mathrm{Ln}=\mathrm{Tb}$ ) in proteins and enzymes provides a tool for estimating intramolecular $\mathrm{Ln}-\mathrm{M}$ distances because the d-block ions $\left(\mathrm{Mn}^{\mathrm{II}}, \mathrm{Fe}^{\mathrm{II}}, \mathrm{Fe}^{\mathrm{III}}, \mathrm{Co}^{\mathrm{II}}\right)$ quench the $\mathrm{Ln}$ centred emission in a predictable way. ${ }^{17}$ These energy transfers are not limited to blocked conformations in the solid state and closely diffusing d-block complexes in solution may interact with lanthanide complexes in their excited states as demonstrated by Richardson, Riehl and co-workers for the quenching of the nine-co-ordinate monometallic triple-helical complexes $\left[\mathrm{LnL}_{3}\right]^{3-}(\mathrm{L}$ is a 4-substituted pyridine-2,6-dicarboxylate) by $\left[\mathrm{Co}(\mathrm{en})_{3}\right]^{3+}$ (en is 1,2-ethylenediamine) or $\left[\mathrm{Co}(\mathrm{phen})_{3}\right]^{3+}$ (phen is 1,10-phenanthroline). ${ }^{18} \mathrm{~A}$ related detailed analysis of intermolecular $\mathrm{d} \leftrightarrow \mathrm{f}$ energy transfer processes in 85 solids of general formula $\left[\mathrm{ML}_{6}\right]\left[\mathrm{Ln}(\text { dipicolinate })_{3}\right](\mathrm{M}=\mathrm{Cr}$ or $\mathrm{Co} ; \mathrm{L}=$ urea, ammonia, various amines) shows that $\mathrm{Co}^{\mathrm{III}}$ is an efficient nonemitting acceptor for $\mathrm{Ln}=\mathrm{Eu}$ or $\mathrm{Tb}$, while the red-emitter $\mathrm{Cr}^{\mathrm{III}}$ can act as a donor and/or an acceptor which is compatible with light conversion involving Ln-Cr pairs. ${ }^{19}$ Surprisingly, the specific structural, thermodynamic and electronic effects associated with the chemical and/or mechanical coupling occurring between the metallic sites have been poorly investigated and this probably results from the limited control over the lanthanide co-ordination site. Since 1995, we have launched into a project aiming at the development of segmental receptors which are predisposed for the self-assembly of isolated $\mathrm{d}-\mathrm{f}$ pairs in which each metallic site possesses predetermined structural, thermodynamic and electronic properties. The subtle synergetic effects occurring between the two metallic sites can thus be explored by detecting minor deviations in the luminescent and magnetic properties.

\section{Self-assembly of discrete heterodimetallic d-f triple- stranded helicates}

Molecular recognition processes involving ligands and metal ions have reached such a point that multi-component selfassemblies of metallosupramolecular complexes in solution

Stéphane Rigault studied Physics and Mathematics at the University of Rennes (France) from 1988 to 1993. He earned a degree in Physical Chemistry in 1994 (University of Strasbourg) and joined the group of Prof. C. Piguet in 1996. During his PhD, he has developed new paramagnetic NMR techniques for characterizing heterometallic helicates.

Gérald Bernardinelli received his M.S. degree in chemistry in 1973 and his PhD in 1978 in the domain of structural chemistry of macrocyclic musks (University of Geneva). From 1978 to 1983, he was a Research Chemist in the field of X-ray crystallography. Since 1983 he works as an Associated Professor in the Laboratory of Crystallography of the University of Geneva where he is responsible for the structural determination of organic and organometallic compounds by X-ray diffraction. His scientific interests are X-ray diffraction analysis in relation to structural chemistry of small and medium size molecules.

Gérard Hopfgartner received his PhD in 1991 in the field of organic geochemistry and mass spectrometry (University of Geneva). He pursued his formation as a postdoctoral fellow at Cornell University in the group of Prof. J. Henion and he then joined Hoffmann-La Roche in Basle (Switzerland). He is currently Head of the Bioanalytical Section. His scientific interests are mass spectrometry, $L C-M S, C E-M S$, quantitative analysis, structure elucidation of metabolites, and fragmentation mechanisms in collision induced dissociation

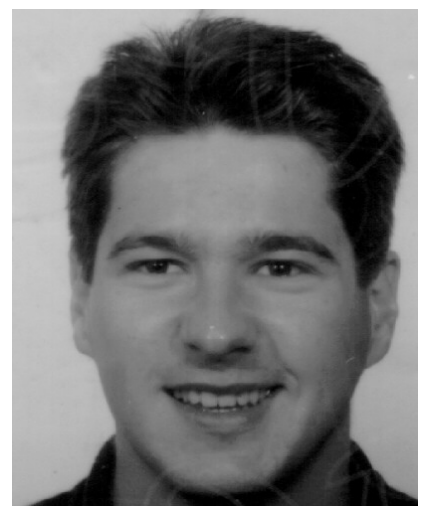

Stéphane Rigault

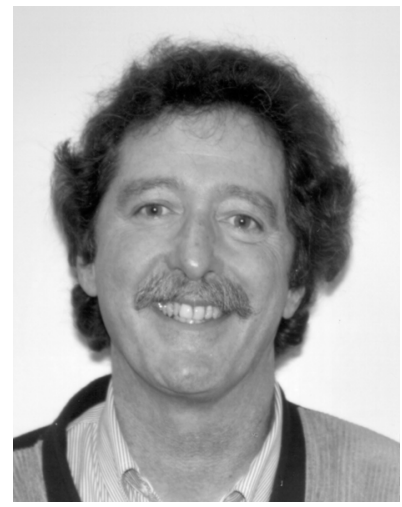

Gérald Bernardinelli

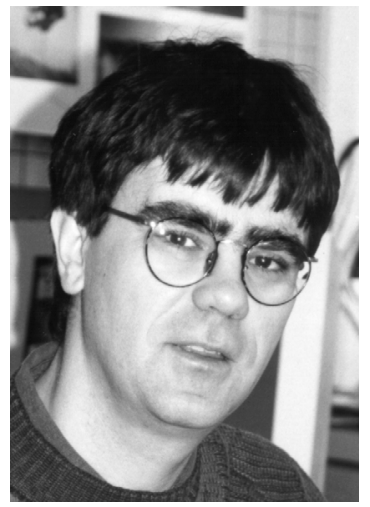

Gérard Hopfgartner 
can be programmed, thus leading to fascinating organised architectures such as helicates, ${ }^{20}$ grids and racks, ${ }^{21}$ boxes, ${ }^{22}$ catenates, ${ }^{23}$ metallacrowns ${ }^{24}$ and symmetrical clusters. ${ }^{25}$ These complexes generally contain d-block ions as structural components because they display variable and pronounced stereochemical preferences associated with strong dative bonds with $\mathrm{N}$ - or O-donor ligands. The first triple-stranded helicates indeed resulted from the complexation of three bis-bidentate segmental ligands with d-block ions, ${ }^{26}$ but an extension toward f-block ions has later been demonstrated for related edifices in which three helically wrapped bistridentate receptors are complexed to nine-co-ordinate tricapped-trigonal prismatic $\mathrm{Ln}^{\mathrm{III}}{ }^{27}$ Combining both aspects provides the segmental ligand $\mathrm{L}^{1}$ which possesses a bidentate 2-(benzimidazolyl)pyridine unit coded for complexing soft pseudo-octahedral d-block ions and a tridentate 2,6-bis(benzimidazolyl)pyridine unit coded for nine-co-ordinate f-block ions. The methylene spacer connecting the binding units in $\mathrm{L}^{1}$ prevents their simultaneous co-ordination to the same metal ion and induces an helical twist within the receptor. ${ }^{28}$ Reactions of $\mathrm{L}^{1}$ with either $\mathrm{Zn}^{\mathrm{II}}$ or $\mathrm{La}^{\mathrm{III}}$, or with a mixture of the two metal ions, have carefully been investigated by a combination of suitable techniques (see below), thus leading to a complete picture of the thermodynamic assembly processes occurring in solution (Fig. 1) ${ }^{29}$ Four different complexes have been detected and, because of the fast dynamics of the thermodynamic equilibria, any complex can be prepared pure or as the major component existing in solution via a judicious set of experimental conditions (stoichiometry, concentrations). For instance, the desired $C_{3}$-symmetrical heterodimetallic $\mathrm{d}-\mathrm{f}$ triple-stranded helicate (HHH)-[LaZn$\left.\left(\mathrm{L}^{1}\right)_{3}\right]^{5+}$ corresponds to $>90 \%$ of the ligand speciation for a $\mathrm{La}: \mathrm{Zn}: \mathrm{L}^{1}$ ratio of $1: 1: 3$ and a total ligand concentration larger than $0.01 \mathrm{M} .{ }^{29}$ Related combinations of thermodynamic equilibria have recently been described as 'dynamic virtual combinatorial libraries' ${ }^{30}$ because any component or complex can be 'expressed' under a set of suitable experimental conditions, but only few have been quantitatively rationalised in terms of stability constants.

Despite its coding for the complexation of $\mathrm{Ln}^{\mathrm{III}}$, the considerable affinity of the tridentate binding segment of $\mathrm{L}^{1}$ for d-block ions $\left(\mathrm{M}=\mathrm{Zn}^{\mathrm{II}}\right.$ or $\left.\mathrm{Fe}^{\mathrm{II}}\right)$ strongly limits selective formation of the heterodimetallic helicates $(\mathrm{HHH})-\left[\operatorname{LnM}\left(\mathrm{L}^{1}\right)_{3}\right]^{5+}$ and intricate mixtures of complexes are observed for ligand concentrations below $0.005 \mathrm{M}^{29,31}$ The replacement of the terminal benzimidazole ring of $\mathrm{L}^{1}$ by a carboxamide group in $\mathrm{L}^{2}$ simultaneously improves the affinity of the tridentate unit for $\mathrm{Ln}^{\mathrm{III}}$ and decreases its tendency to complex soft d-block ions. ${ }^{32}$ The stability constant of the heterodimetallic complex $(\mathrm{HHH})-\left[\mathrm{LaZn}\left(\mathrm{L}^{2}\right)_{3}\right]^{5+}$ is larger than that observed for $\mathrm{L}^{1}$ and the associated improved selectivity of the assembly process leads to the quantitative formation $(>95 \%)$ of $(\mathrm{HHH})$ $\left[\mathrm{LaZn}\left(\mathrm{L}^{2}\right)_{3}\right]^{5+}$ in acetonitrile for a $\mathrm{La}: \mathrm{Zn}: \mathrm{L}^{2}$ ratio of $1: 1: 3$ and a total ligand concentration of $10^{-4} \mathrm{M}^{32}$ On the other hand, the reactions of $\mathrm{L}^{2}$ with either $\mathrm{La}^{\mathrm{III}}$ or $\mathrm{Zn}^{\mathrm{II}}$ produce intricate mixtures of homopolymetallic complexes with variable stoichiometries and structures $\left(\left[\mathrm{Zn}\left(\mathrm{L}^{2}\right)_{3}\right]^{2+},\left[\mathrm{Zn}_{2}\left(\mathrm{~L}^{2}\right)_{3}\right]^{4+},\left[\mathrm{Zn}_{2}-\right.\right.$ $\left.\left.\left(\mathrm{L}^{2}\right)_{2}\right]^{4+},\left[\mathrm{La}\left(\mathrm{L}^{2}\right)_{3}\right]^{3+},\left[\mathrm{La}_{2}\left(\mathrm{~L}^{2}\right)_{3}\right]^{6+}\right)$ resulting from the incorrect matching between the intrinsic information encoded in the ligand and the metal ions and this contrasts with the clean complexation processes observed for $\mathrm{L}^{1}$ under similar conditions (Figs. 1 and 2). ${ }^{32}$

Although most metallosupramolecular complexes are dynamically inert and well defined on the NMR timescale, they remain labile on a preparative timescale and variations of the experimental conditions produce fast re-equilibration which may destroy the desired complex, a strongly limiting factor when functional devices in solution are to be designed. Isolation and crystallisation is the usual technique to solve this problem because no fast re-equilibration of the products occurs

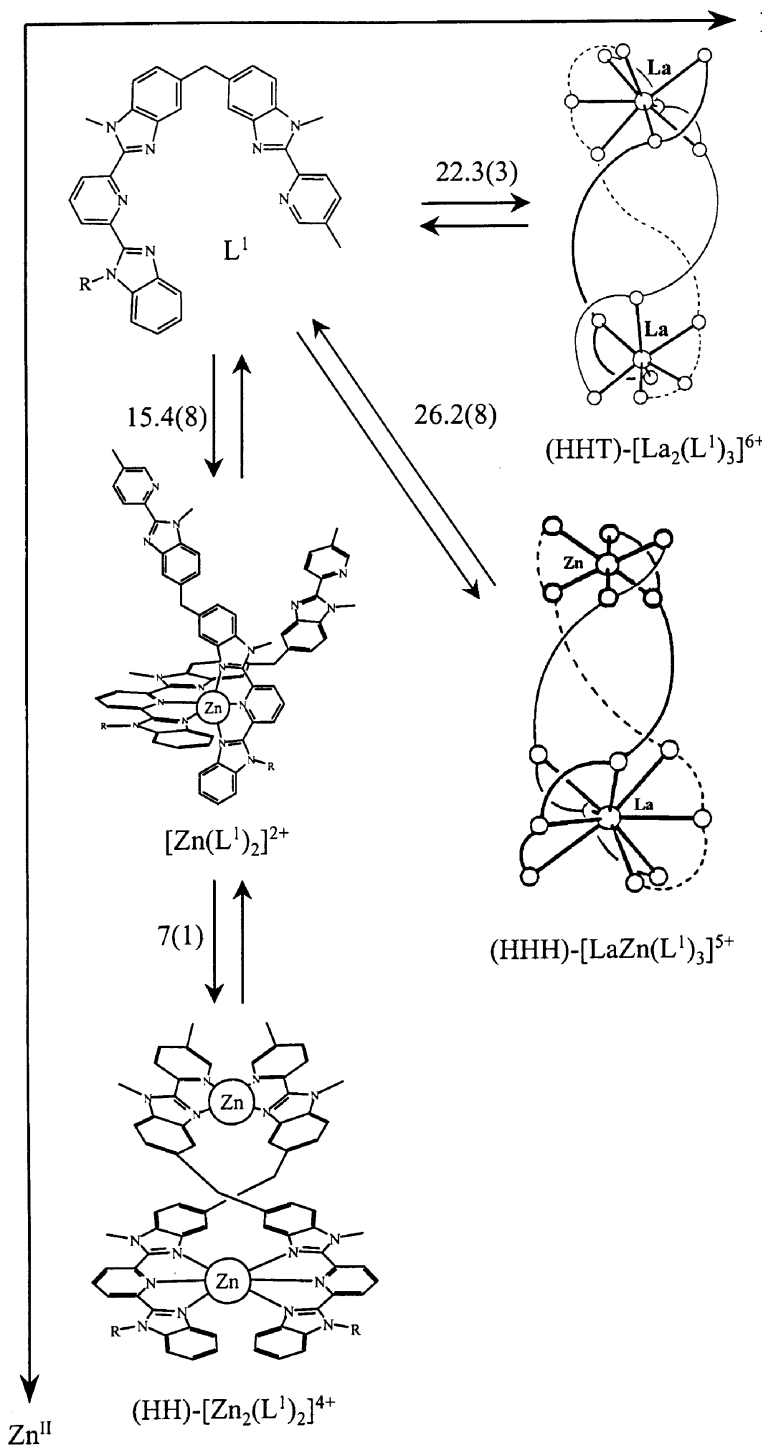

Fig. 1 Self-assembly of $\mathrm{L}^{1}$ with $\mathrm{La}^{\mathrm{III}}$ and $\mathrm{Zn}^{\mathrm{II}}$ in acetonitrile. The stability constant $\log K$ for each defined equilibrium is given $(\mathrm{R}=3,5$ dimethylbenzyl).

in the solid state, but the introduction of dynamically inert $\mathrm{Co}^{\mathrm{III}}$ ( $\mathrm{d}^{6}$ low spin) is an alternative approach which ensures rigidity and inertness in solution and in the solid state. However, fast dynamic redistributions and reversibility are fundamental requirements in thermodynamic (= strict) self-assembly processes for which the complete energy hypersurface must be explored. ${ }^{9,33}$ Therefore, the introduction of dynamically inert $\mathrm{Co}^{\text {III }}$ involves the use of a labile high spin cobalt(II) precursor in the self-assembled helicate $(\mathrm{HHH})-\left[\mathrm{LnCo}\left(\mathrm{L}^{2}\right)_{3}\right]^{5+}$ which is then oxidised to (HHH)-[LnCo $\left.\left(\mathrm{L}^{2}\right)_{3}\right]^{6+}$ during the post-modification process (Fig. 3). ${ }^{34}$ The inert and diamagnetic pseudo-octahedral cobalt(III) site acts as a tripod which organises the three tridentate binding units for their complexation to $\mathrm{Ln}^{\mathrm{III}}$ leading to the term of non-covalent lanthanide podates for describing this class of supramolecular complexes. ${ }^{32,34}$ Interestingly, $\mathrm{Ln}^{\mathrm{III}}$ can be extracted from $(\mathrm{HHH})-\left[\mathrm{LnCo}\left(\mathrm{L}^{2}\right)_{3}\right]^{6+}$ by treatment with EDTA $^{4-}$, thus producing the facial inert nine-co-ordinate podand $\mathrm{fac}-\left[\mathrm{Co}\left(\mathrm{L}^{2}\right)_{3}\right]^{3+}$ (Fig. 3$)$. $^{34}$

Potential applications of these $\mathrm{d}-\mathrm{f}$ complexes as functional devices require fine tuning of the electronic properties of the d-block tripod together with improved stability and solubility in aqueous media. In $\left[\mathrm{L}^{3}-\mathrm{H}\right]^{-}$the presence of a terminal carboxylate improves the affinity of the tridentate segment for $\mathrm{Ln}^{\mathrm{III}}$ and provides triple-helical d-f helicates $(\mathrm{HHH})-\left[\mathrm{LnZn}\left(\mathrm{L}^{3}-\right.\right.$ $\left.\mathrm{H})_{3}\right]^{2+}$ which are stable in strongly co-ordinating solvents. ${ }^{35}$ 


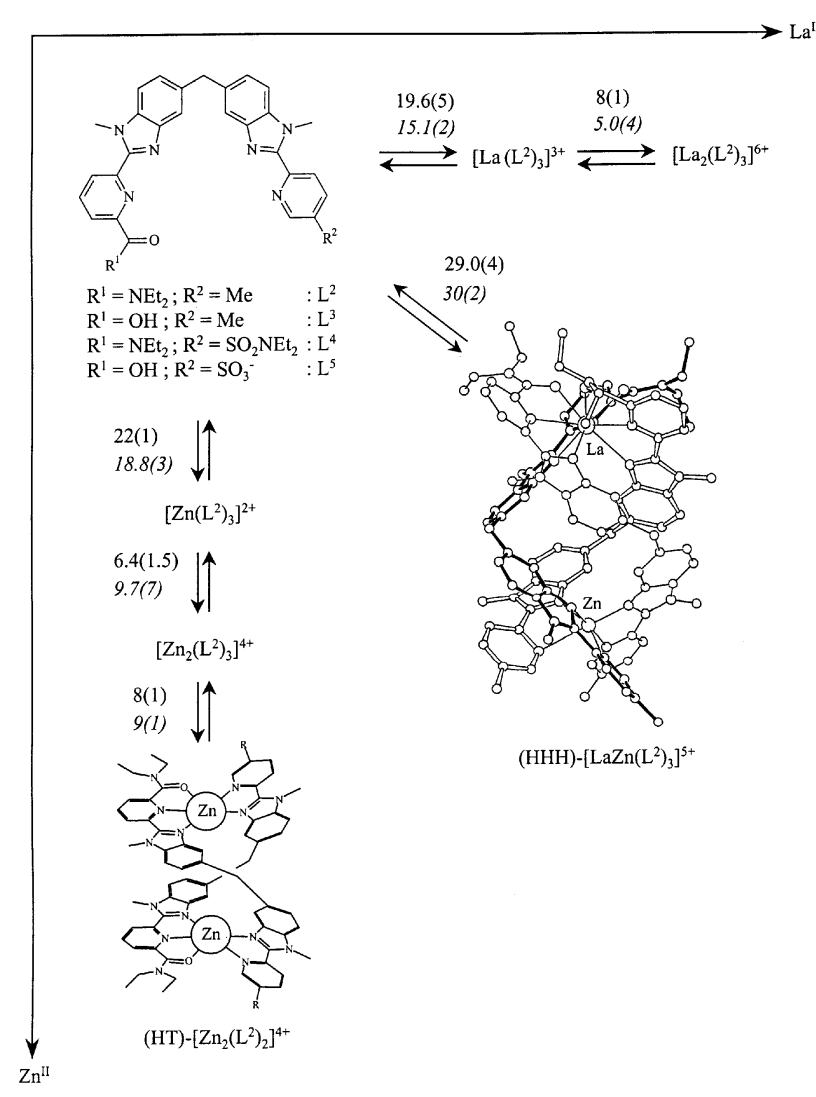

Fig. 2 Self-assembly of $\mathrm{L}^{2}$ and $\mathrm{L}^{4}$ with $\mathrm{La}^{\mathrm{III}}$ and $\mathrm{Zn}^{\mathrm{II}}$ in acetonitrile. The stability constant $\log K$ for each defined equilibrium is given using regular $\left(\mathrm{L}^{2}\right)$ and italic fonts $\left(\mathrm{L}^{4}\right)$.
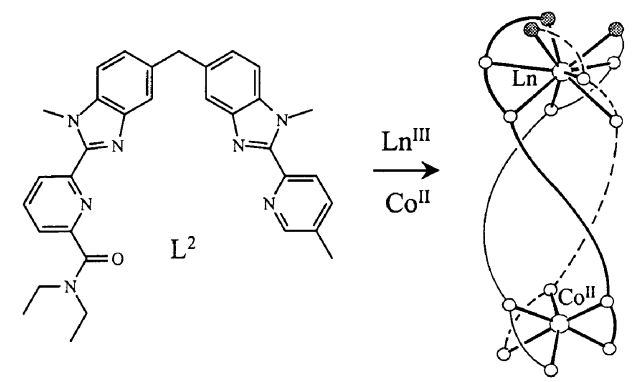

$(\mathrm{HHH})-\left[\mathrm{LnCo}\left(\mathrm{L}^{2}\right)_{3}\right]^{5+}$

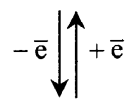

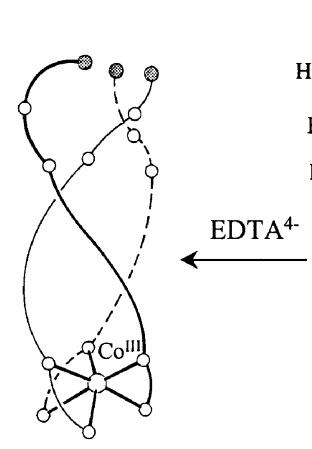

$\mathrm{FAC}-\left[\mathrm{Co}\left(\mathrm{L}^{2}\right)_{3}\right]^{3+}$

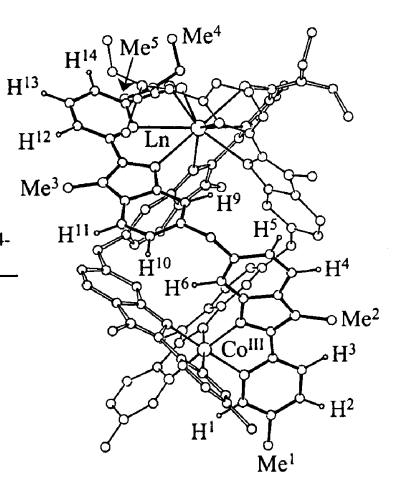

$(\mathrm{HHH})-\left[\mathrm{LnCo}\left(\mathrm{L}^{2}\right)_{3}\right]^{6+}$
Fig. 3 Self-assembly of $(\mathrm{HHH})-\left[\mathrm{LnCo}\left(\mathrm{L}^{2}\right)_{3}\right]^{5+}$ followed by oxidation (post-modification) to give $(\mathrm{HHH})-\left[\mathrm{LnCo}\left(\mathrm{L}^{2}\right)_{3}\right]^{6+}$. A subsequent partial decomplexation in acetonitrile produces the nine-co-ordinate receptor fac- $\left[\mathrm{Co}\left(\mathrm{L}^{2}\right)_{3}\right]^{3+}$

Luminescence measurements demonstrate that the red-emissive complex $(\mathrm{HHH})-\left[\mathrm{EuZn}\left(\mathrm{L}^{3}-\mathrm{H}\right)_{3}\right]^{2+}\left(\Phi_{\text {abs }}\left(\mathrm{CH}_{3} \mathrm{CN}\right)=0.013\right)$ is as luminescent as $\left[\mathrm{Eu}(\text { terpy })_{3}\right]^{3+}$ under the same conditions and remains intact in water at very low concentrations $\left(10^{-8} \mathrm{M}\right)$, a crucial point for the design of responsive systems for the analysis of biological material. ${ }^{35} \mathrm{~A}$ recent implementation of terminal carboxylate groups onto a ditopic ligand coded for the design of $\mathrm{f}-\mathrm{f}$ edifices has produced the first homodimetallic lanthanide-containing helicates which are luminescent $\left(\Phi_{\text {abs }}\left(\mathrm{H}_{2} \mathrm{O}\right)=0.013\right)$ and highly stable in water. ${ }^{27 c}$ However, the polar carboxylate group of $\left[\mathrm{L}^{3}-\mathrm{H}\right]^{-}$dramatically limits the solubility of the ligand and its complexes in nonpolar solvents, while the lipophilic part of the molecule prevents solubility in polar solvents. Consequently, the final helicates $(\mathrm{HHH})-\left[\mathrm{EuZn}\left(\mathrm{L}^{3}-\mathrm{H}\right)_{3}\right]^{2+}$ are inevitably obtained from two-phase reactions and no quantitative thermodynamic data are accessible. In order to combine the beneficial aspect of carboxylate groups for complexing $\mathrm{Ln}^{\text {III }}$ with a satisfying solubility, we have recently prepared $\mathrm{L}^{5}$ whose sulfonate group ensures solubility in water, ${ }^{36}$ but the connection of an electron-withdrawing group to the bidentate binding unit may severely affect the structural, thermodynamic and electronic properties of the pseudo-octahedral d-block tripod. Therefore, $\mathrm{L}^{4}$ has been investigated as a model of $\mathrm{L}^{5}$ which is soluble in acetonitrile. The lower stability found for the lanthanide complexes $\left[\mathrm{La}\left(\mathrm{L}^{4}\right)_{3}\right]^{3+},\left[\mathrm{La}_{2}\left(\mathrm{~L}^{4}\right)_{3}\right]^{6+}$ compared with those obtained for $\mathrm{L}^{2}$ are assigned to the expected reduced $\sigma$ donation of the pyridine ring bearing a sulfonamide group. On the other hand, the comparable stabilities observed for $\left[\mathrm{Zn}_{2}\left(\mathrm{~L}^{i}\right)_{3}\right]^{4+},\left[\mathrm{Zn}_{2}\left(\mathrm{~L}^{i}\right)_{2}\right]^{4+}$ and $(\mathrm{HHH})-\left[\operatorname{LaZn}\left(\mathrm{L}^{i}\right)_{3}\right]^{5+}(i=2$ or 4$)$ contrast with the latter statement and point to $\sigma / \pi$ compensation effects for the complexation of soft d-block ions. ${ }^{36}$ Theoretical calculations at the $a b$ initio level show that the sulfonamide group brings an extra stabilisation of the $\pi$ LUMO which favours back donation with electron-rich d-block ions possessing filled d orbitals with adapted symmetries (low spin $\mathrm{Fe}^{\mathrm{II}}, \mathrm{Ni}^{\mathrm{II}}, \mathrm{Zn}^{\mathrm{II}}$ ), while interactions between metal and ligand-centred $\sigma$ orbitals are concomitantly reduced. ${ }^{36}$ An electron-withdrawing sulfonamide group bound to the terminal pyridine ring is thus tolerated in the self-assembly process in that the lower $\sigma$ bonding is compensated by larger $\pi$ back bonding upon complexation to the d-block ion. This opens new perspectives for fine tuning of the electronic properties of the non-covalent tripod (see below) and for self-assembled $\mathrm{d}-\mathrm{f}$ helicates with $\left[\mathrm{L}^{5}-\mathrm{H}\right]^{2-}$ in water.

\section{Characterisation of heterodimetallic d-f helicates}

The complete exploration and characterisation of the assembly processes shown in Figs. 1-3 require precise knowledge of the speciation in solution, which relies on ESI-MS titrations for establishing the absolute stoichiometries of the complexes and spectrophotometry or potentiometry for obtaining a predictive quantitative model. ${ }^{20,37}$ However, reliable structural investigations of metallosupramolecular architectures mainly depend on the determination of crystal structures in the solid state which suffer from three limiting factors: (i) crystals of sufficient quality must be obtained, but large and flexible assemblies or aggregates often fail to give satisfying results, (ii) packing forces occurring during the crystallisation process have no counterpart in solution and may significantly alter the structure of the complex and (iii) the complex which crystallises often corresponds to the less soluble component of the thermodynamic assembly process under a set of experimental conditions and minor species can be isolated instead of the desired major component. Nevertheless, X-ray diffraction remains the ultimate proof for the formation of the heterodimetallic triple-stranded helicates and the crystal structures of $(\mathrm{HHH})-\left[\mathrm{LnM}^{\mathrm{II}}\left(\mathrm{L}^{2}\right)_{3}\right]^{5+}$ $\left(\mathrm{EuZn}^{32}\right.$ and $\left.\mathrm{LaFe}^{38}\right)$, ( $\left.\mathrm{HHH}\right)-\left[\mathrm{LnM}^{\mathrm{III}}\left(\mathrm{L}^{2}\right)_{3}\right]^{6+}\left(\mathrm{LaCo}^{34}\right.$ and $\left.\mathrm{LuCo}^{39}\right)$ and $(\mathrm{HHH})-\left[\mathrm{EuZn}\left(\mathrm{L}^{4}\right)_{3}\right]^{5+36}$ strongly support their formation in solution. The majority of the complexes involved in the self-assembly processes of Figs. 1 and 2 have escaped structural characterisations by X-ray diffraction studies 


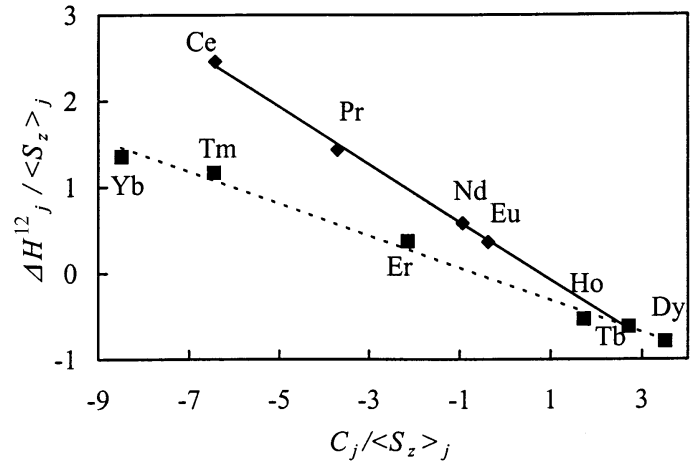

Fig. 4 Plot of $\Delta_{i j} /\left\langle S_{z}\right\rangle_{j}$ vs. $C_{j} /\left\langle S_{z}\right\rangle_{j}$ (a linear form of eqn. (1)) ${ }^{39}$ for $\mathrm{H}^{12}$ in $(\mathrm{HHH})-\left[\mathrm{LnCoL}_{3}\right]^{6+}$ (acetonitrile, $298 \mathrm{~K}$ ) showing the break in the middle of the lanthanide series.

because no suitable crystals could be grown. Moreover, the resolution of the crystal structures for these large complexes is often complicated and time consuming ${ }^{20}$ and it is of minor interest to solve solid-state structures for all $\mathrm{d}-\mathrm{f}$ pairs of interest for further applications (see below). We have thus resorted to NMR spectroscopy to investigate these complexes in solution and the combination of usual techniques $\left({ }^{1} \mathrm{H}\right.$ NMR, $\left\{{ }^{1} \mathrm{H}-{ }^{1} \mathrm{H}\right\}$ COSY, $\left\{{ }^{1} \mathrm{H}-{ }^{1} \mathrm{H}\right\}$ NOESY and related heteronuclear correlation methods) with variable temperature measurements provides satisfying structural characterisations for diamagnetic or weakly paramagnetic complexes in solution. However, the correct assignment of NMR spectra for strongly paramagnetic complexes is precluded by their large electronic magnetic moments which dramatically increase nuclear relaxation and linewidth. The latter limitation can be turned to an advantage if we are able satisfyingly to rationalise paramagnetic interactions because structural parameters (internal axial coordinates) and electronic characteristics (hyperfine coupling constants) can be extracted from paramagnetic NMR induced shifts. The complexes $(\mathrm{HHH})-\left[\mathrm{LnCo}\left(\mathrm{L}^{2}\right)_{3}\right]^{6+}$ are particularly attractive in this context because the cobalt(III) tripod is diamagnetic and dynamically inert and $\mathrm{Ln}^{\mathrm{III}}$ remains the single paramagnetic site in these axial complexes. Under these conditions, the experimentally accessible paramagnetic NMR shift $\Delta_{i j}$ induced at a nucleus $i$ of a ligand bound to lanthanide $j$ can be expressed as the sum of the paramagnetic contact shift $\delta_{i j}^{\mathrm{c}}$ (associated with through-bond Fermi interactions) ${ }^{40}$ and the paramagnetic pseudo-contact shift $\delta_{i j}^{\mathrm{pc}}$ (associated with the residual throughspace dipolar interactions), ${ }^{41}$ eqn (1). As the electronic proper-

$$
\Delta_{i j}=\delta_{i j}^{\mathrm{exp}}-\delta_{i}^{\mathrm{dia}}=\delta_{i j}^{\mathrm{c}}+\delta_{i j}^{\mathrm{pc}}=F_{i}\left\langle S_{z}\right\rangle_{j}+G_{i} A_{2}^{0}\left\langle r^{2}\right\rangle C_{j}
$$

ties of $\mathrm{Ln}^{\mathrm{III}}$ are not significantly perturbed by complexation, the specific magnetic constants of the lanthanide $j$ tabulated for the free ions (the projection of the total electron spin magnetisation onto the direction of the external magnetic field $\left\langle S_{z}\right\rangle_{j}$, and the second-order magnetic axial anisotropy $C_{j}$ ) can be used. Eqn. (1) is thus linear along the lanthanide series at a given temperature if the hyperfine coupling constant $F_{i}$ and pseudo-contact term $G_{i} A_{2}^{0}\left\langle r^{2}\right\rangle$ (which depends on the axial co-ordinates $G_{i}=\left(1-3 \cos ^{2} \theta_{i}\right) / r_{i}^{3}$ and on the crystal field parameter $\left.A_{2}^{0}\left\langle r^{2}\right\rangle\right)$ of a given nucleus $i$ are constant along the lanthanide series. For $(\mathrm{HHH})-\left[\mathrm{LnCo}\left(\mathrm{L}^{2}\right)_{3}\right]^{6+}$, we systematically observe a break around the middle of the series ( $\mathrm{Ln}=\mathrm{Tb}$ or $\mathrm{Dy}$ ) for linear forms of eqn. (1) which was assigned originally to a structural change $^{42}$ (variation of $G_{i}$ ) occurring between large and small lanthanides (Fig. 4). ${ }^{34,39}$

However, the crystal structures of $(\mathrm{HHH})-\left[\mathrm{LnCo}\left(\mathrm{L}^{2}\right)_{3}\right]^{6+}$ $(\mathrm{Ln}=\mathrm{La} \text { or } \mathrm{Lu})^{34,39}$ are very similar and do not support this hypothesis and we have resorted to a recently developed crystalfield independent method (eqn. (2)) ${ }^{43}$ to clarify the situation. ${ }^{39}$

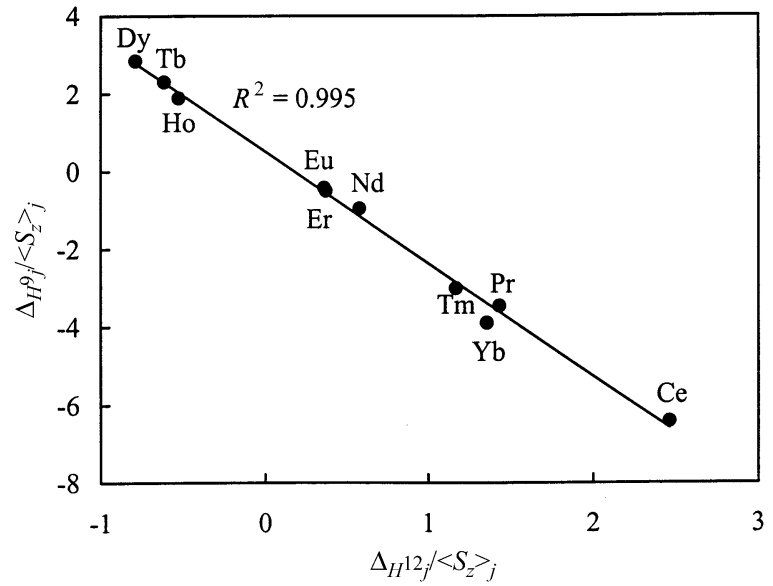

Fig. 5 Plot of $\Delta_{i j} /\left\langle S_{z}\right\rangle_{j} v s . \Delta_{k j} /\left\langle S_{z}\right\rangle_{j}$ according to eqn. (2) for $\mathrm{H}^{9}-\mathrm{H}^{12}$ in (HHH)-[LnCoL $]^{6+}$ (acetonitrile, $298 \mathrm{~K}$ ).

$$
\frac{\Delta_{i j}}{\left\langle S_{z}\right\rangle_{j}}=\left(F_{i}-F_{k} \cdot \frac{G_{i}}{G_{k}}\right)+\frac{G_{i}}{G_{k}} \cdot \frac{\Delta_{k j}}{\left\langle S_{z}\right\rangle_{j}}
$$

We indeed found that plots of $\Delta_{i j} /\left\langle S_{z}\right\rangle_{j} v s . \Delta_{k j} /\left\langle S_{z}\right\rangle_{j}$ for each pair of protons $\mathrm{H}^{i}, \mathrm{H}^{k}$ in the complexes $(\mathrm{HHH})-\left[\mathrm{LnCo}\left(\mathrm{L}^{2}\right)_{3}\right]^{6+}$ are linear $(\mathrm{Ln}=\mathrm{Ce}$ to $\mathrm{Yb})$, thus implying the existence of a single three-dimensional structure in solution along the complete lanthanide series in agreement with the crystal structures found in the solid state (Fig. 5). The 'apparent' break obtained with eqn. (1) corresponds to simultaneous changes of the crystal field parameter $A_{2}^{0}\left\langle r^{2}\right\rangle$ and the hyperfine constants $F_{i}$ when the $4 \mathrm{f}$ shell is more than half-filled. ${ }^{4}$ This new method (eqn. (2)) is the only technique allowing a reliable structural exploration of paramagnetic lanthanide complexes by NMR in solution and recent developments show that valuable predictions for strongly paramagnetic complexes $(\mathrm{HHH})-\left[\mathrm{LnCo}\left(\mathrm{L}^{2}\right)_{3}\right]^{6+}(\mathrm{Ln}=\mathrm{Tb}$ to Er) allow the rationalisation of their NMR spectra which significantly improves the final structural analysis. ${ }^{44}$ Successful derivations of related equations for paramagnetic complexes containing two uncoupled paramagnetic centres in (HHH)$\left[\mathrm{LnCo}\left(\mathrm{L}^{2}\right)_{3}\right]^{5+}\left(\mathrm{Co}^{\mathrm{II}} \text { or } \mathrm{Ln}^{\mathrm{III}}\right)^{45}$ and in homodimetallic $\mathrm{f}-\mathrm{f}$ triplestranded helicates ${ }^{27 c, 39}$ open new perspectives for characterising complicated lanthanide-containing architectures without systematically resorting to X-ray diffraction studies in the solid state.

\section{Programming electronic, magnetic and photophysical properties}

In order to simplify the characterisation of self-assembly processes leading to heterodimetallic complexes (HHH)-[LnM$\left.\left(\mathrm{L}^{i}\right)_{3}\right]^{5+}(i=1,2$ or 4$)$ and $(\mathrm{HHH})-\left[\operatorname{LnM}\left(\mathrm{L}^{3}-\mathrm{H}\right)_{3}\right]^{2+}$, we first use $\mathrm{Zn}^{\mathrm{II}}$ in the non-covalent tripod because its $\mathrm{d}^{10}$ electronic configuration (i) does not interfere with electronic, magnetic or optical properties of lanthanide(III) ions and (ii) displays weak stereochemical preferences and tolerates severe distortions of the pseudo-octahedral site depending on the size of $\mathrm{Ln}^{\text {III }}$. Therefore, the complexes $(\mathrm{HHH})-\left[\operatorname{LnZn}\left(\mathrm{L}^{i}\right)_{3}\right]^{5+}(i=1,2$ or 4$)$ and $(\mathrm{HHH})-\left[\mathrm{LnZn}\left(\mathrm{L}^{3}-\mathrm{H}\right)_{3}\right]^{2+}$ are ideally suited to explore the photophysical properties of nine-co-ordinate $\mathrm{Ln}^{\mathrm{III}}$. For the first generation of heterodimetallic helicates $(\mathrm{HHH})-\left[\operatorname{LnZn}\left(\mathrm{L}^{1}\right)_{3}\right]^{5+}$ $(\mathrm{Ln}=\mathrm{Eu}$ or $\mathrm{Tb})$ the luminescence is faint at room temperature in the solid state and in solution $\left(\Phi_{\text {abs }}=1.3 \times 10^{-6}\right.$ in acetonitrile upon UV irradiation!) and only low temperature measurements $(10 \mathrm{~K})$ reveal well resolved emission spectra. ${ }^{29} \mathrm{~A}$ closely related behaviour has been observed for the analogous co-ordination site found in tris(2,6-bis(benzimidazolyl)pyridine)europium(III) which has been ascribed to an efficient quenching of the ligand $\rightarrow \mathrm{Eu}^{\mathrm{III}}$ energy transfer by low-energy 


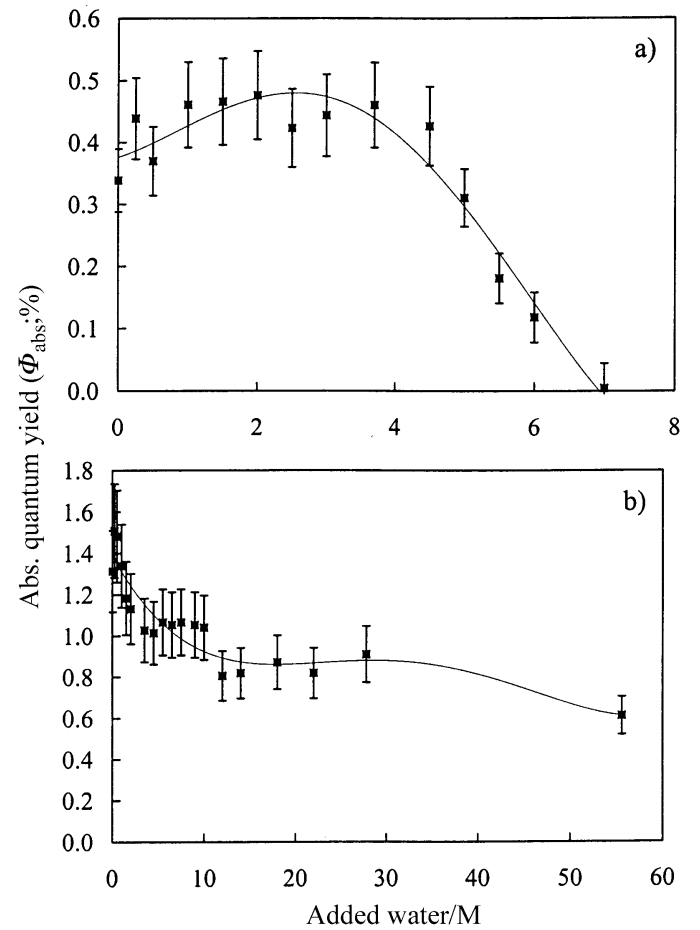

Fig. 6 Absolute quantum yields in acetonitrile versus the concentration of added water for (a) $(\mathrm{HHH})-\left[\operatorname{EuZn}\left(\mathrm{L}^{4}\right)_{3}\right]^{5+}$ and (b) $(\mathrm{HHH})-$ $\left[\mathrm{EuZn}\left(\mathrm{L}^{3}-\mathrm{H}\right)_{3}\right]^{2+}$.

LMCT states. ${ }^{46}$ This explanation also holds for $(\mathrm{HHH})$ $\left[\operatorname{EuZn}\left(\mathrm{L}^{1}\right)_{3}\right]^{5+}$, while the proximity of the ligand-centred ${ }^{3} \pi \pi^{*}$ and $\mathrm{Tb}\left({ }^{5} \mathrm{D}_{4}\right)$ energy levels in $(\mathrm{HHH})-\left[\mathrm{TbZn}\left(\mathrm{L}^{1}\right)_{3}\right]^{5+}$ is responsible for a thermally activated energy back transfer which prevents detection of metal-centred emission at room temperature. ${ }^{47}$ The replacement of the terminal benzimidazole of $\mathrm{L}^{1}$ by a carboxamide group in $\mathrm{L}^{2}$ shifts the LMCT states toward higher energy in $(\mathrm{HHH})-\left[\mathrm{EuZn}\left(\mathrm{L}^{2}\right)_{3}\right]^{5+}$ and restores an easily detectable metal-centred emission upon UV irradiation $\left(\Phi_{\text {abs }}=1.7 \times 10^{-3}\right.$ in acetonitrile $)$. High-resolution emission spectra confirm the axial threefold symmetry of the lanthanide site and its efficient protection from solvent molecules. The modest absolute quantum yield is mainly due to poorly efficient ${ }^{1} \pi \pi^{*} \longrightarrow{ }^{3} \pi \pi^{*}$ intersystem crossing and very similar photophysical properties characterise the analogous complex $(\mathrm{HHH})-\left[\mathrm{EuZn}\left(\mathrm{L}^{4}\right)_{3}\right]^{5+}$ because the sulfonamide groups have no effect on the lanthanide co-ordination site. ${ }^{36}$ Interestingly, $(\mathrm{HHH})-\left[\mathrm{EuZn}\left(\mathrm{L}^{4}\right)_{3}\right]^{5+}$ is quite resistant toward hydrolysis and the addition of $4 \mathrm{M}$ water in acetonitrile is tolerated prior to decomplexation (Fig. 6a). ${ }^{36}$ The use of $\mathrm{L}^{3}$ significantly improves the photophysical properties of the complex $(\mathrm{HHH})-\left[\operatorname{EuZn}\left(\mathrm{L}^{3}-\mathrm{H}\right)_{3}\right]^{2+}$ and, despite low solubility in polar and non-polar solvents, the $\mathrm{Eu}\left({ }^{5} \mathrm{D}_{0}\right)$ luminescence is easily detected at low concentration in acetonitrile $\left(\Phi_{\text {abs }}=1.3 \times\right.$ $\left.10^{-2}\right){ }^{35}$ Moreover, resistance toward hydrolysis is drastically improved as a result of the strong $\mathrm{Ln}^{\mathrm{III}}$-carboxylate interaction and quantum yields display minor variations between pure acetonitrile and pure water (Fig. 6b). A recent exploitation of these results provided luminescent homodimetallic $\mathrm{f}-\mathrm{f}$ triplestranded helicates which are good candidates as markers for biological materials. ${ }^{48}$

In $(\mathrm{HHH})-\left[\mathrm{EuZn}\left(\mathrm{L}^{4}\right)_{3}\right]^{5+}$ the pseudo-octahedral zinc tripod acts only as a structural organiser which ensures the facial helical arrangement of the tridentate binding units for their complexation to $\mathrm{Ln}^{\text {III }}$. The replacement of $\mathrm{Zn}^{\text {II }}$ by spectroscopically and magnetically active $\mathrm{Fe}^{\mathrm{II}}$ in $(\mathrm{HHH})-\left[\mathrm{LnFe}\left(\mathrm{L}^{i}\right)_{3}\right]^{5+}$ ( $i=1,2$ or 4 ) offers new perspectives for the design of new electronic, optical and magnetic properties and allows the investigation of possible synergetic effects occurring between

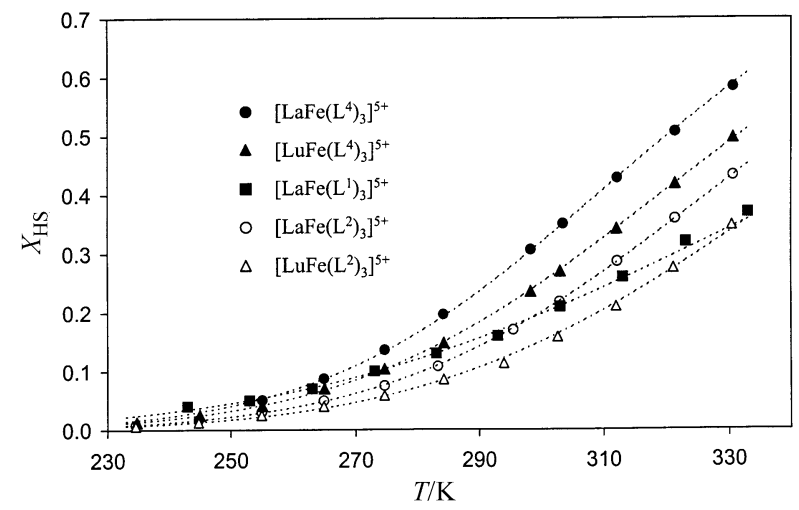

Fig. 7 Mole fraction $\left(x_{\mathrm{hs}}\right)$ of high spin $\mathrm{Fe}^{\mathrm{II}}\left({ }^{5} \mathrm{~T}\right)$ for the thermal spincrossover transition occurring in $(\mathrm{HHH})-\left[\operatorname{LnFe}\left(\mathrm{L}^{i}\right)_{3}\right]^{5+}(i=1,2$ or 4 ; acetonitrile; $233-333 \mathrm{~K}$ ). Dashed lines are calculated with the thermodynamic data given in Table 1 .

the two mechanically coupled metallic sites. As far as photophysical properties are concerned, low spin $\mathrm{Fe}^{\mathrm{II}}$ in $(\mathrm{HHH})-$ $\left[\mathrm{LnFe}\left(\mathrm{L}^{i}\right)_{3}\right]^{5+}$ provides an intense MLCT transition in the visible domain which dominates the absorption spectra and completely quenches Eu-centred emission in (HHH)-[EuFe$\left.\left(\mathrm{L}^{i}\right)_{3}\right]^{5+}$ as a result of efficient intramolecular $\mathrm{Eu} \rightarrow \mathrm{Fe}$ energy transfers. ${ }^{38}$ However, $\mathrm{Fe}^{\mathrm{II}}$ in $(\mathrm{HHH})-\left[\mathrm{LnFe}\left(\mathrm{L}^{i}\right)_{3}\right]^{5+}$ exhibits a non-co-operative spin-crossover process around room temperature which affects magnetic and optical properties in a predictable way. ${ }^{31,36,38}$ For $(\mathrm{HHH})-\left[\mathrm{LnFe}\left(\mathrm{L}^{1}\right)_{3}\right]^{5+}$ the poor stability of the complexes with the heavier $\mathrm{Ln}^{\mathrm{III}}$ restricts the investigations to $\mathrm{Ln}=\mathrm{La}$ to $\mathrm{Eu}$ and very similar enthalpic $\left(\Delta H_{\mathrm{sc}}\right)$ and entropic $\left(\Delta S_{\mathrm{sc}}\right)$ contributions are obtained in acetonitrile for all studied $\operatorname{Ln}^{\text {III }}$ (Table 1). The improved selectivity of the selfassembly processes leading to $(\mathrm{HHH})-\left[\mathrm{LnFe}\left(\mathrm{L}^{i}\right)_{3}\right]^{5+}(i=2$ or 4$)$ gives access to the complete lanthanide series and a dependence of both $\Delta H_{\mathrm{sc}}$ and $\Delta S_{\mathrm{sc}}$ on the size of the lanthanide ions lying in the neighbouring site is unambiguously demonstrated (Table 1 , Fig. 7). ${ }^{36,38}$ Since magnetic coupling between $\mathrm{d}$ - and f-block ions separated by more than $9.0 \AA$ as in $(\mathrm{HHH})-\left[\operatorname{LnFe}\left(\mathrm{L}^{i}\right)_{3}\right]^{5+}(i=2$ or 4) can be neglected, ${ }^{38}$ some specific mechanical coupling promoted by the wrapped ligand strands has been invoked to rationalise the variations of the thermodynamic spin-crossover parameters. Comparable magnetic behaviours are obtained in the solid state and in solution thus pointing to isolated $\mathrm{d}-\mathrm{f}$ pairs in these supramolecular helicates, but lower critical temperatures are required for investigating possible correlations between iron(II) spin states and lanthanide-centred luminescence in $(\mathrm{HHH})-\left[\mathrm{LnFe}\left(\mathrm{L}^{i}\right)_{3}\right]^{5+}(i=2$ or $4 ; \mathrm{Ln}=\mathrm{Eu}$ or $\mathrm{Tb})$.

Initially, $\mathrm{L}^{4}$ was designed to decrease the ligand-field strength of the bidentate binding unit to such a level that (i) the affinity for d-block ion is sufficient to allow the selective self-assembly of the final helicates and (ii) the critical temperatures of spincrossover processes in $(\mathrm{HHH})-\left[\mathrm{LnFe}\left(\mathrm{L}^{4}\right)_{3}\right]^{5+}$ occur below room temperature. Experimental results ${ }^{36}$ show that the ligand-field effects in $(\mathrm{HHH})-\left[\mathrm{LnFe}\left(\mathrm{L}^{i}\right)_{3}\right]^{5+}(i=2$ or 4$)$ are comparable and only minor shifts of the critical temperature result from an increased entropic contribution for the sulfonated ligand. Theoretical calculations at the $a b$ initio level strongly support these observations and suggest that the reduced $\sigma$-donating character of the terminal sulfonated pyridine in $\mathrm{L}^{4}$ is compensated by an improved $\pi$-back-bonding effect with soft d-block ions leading to similar $\mathrm{Fe}-\mathrm{N}$ bond strength. However, the intimate natures of these bonds in the two complexes are completely different and this is evidenced by cyclic voltammetry which shows that the $\mathrm{Fe}^{\mathrm{III}}-\mathrm{Fe}^{\mathrm{II}}$ reduction potential is shifted by $0.35 \mathrm{~V}$ toward negative potential when going from (HHH)$\left[\mathrm{LnFe}\left(\mathrm{L}^{2}\right)_{3}\right]^{5+}$ to $(\mathrm{HHH})-\left[\mathrm{LnFe}\left(\mathrm{L}^{4}\right)_{3}\right]^{5+} .{ }^{36}$ The latter cathodic shift has two origins: (i) a stabilisation of the iron(II) state for $\mathrm{L}^{4}$ compared to $\mathrm{L}^{2}$ (three orders of magnitude in the formation constants) associated with the $\pi$-accepting properties of the 
Table 1 Thermodynamic parameters for the iron(II) ${ }^{1} \mathrm{~A}_{1} \longleftrightarrow{ }^{5} \mathrm{~T}_{2}$ spin-state equilibria observed for $\left[\mathrm{LnFe}\left(\mathrm{L}^{i}\right)_{3}\right]\left[\mathrm{ClO}_{4}\right]_{5}(i=1,2$ or 4$)$ in acetonitrile, as obtained from magnetic measurements

\begin{tabular}{|c|c|c|c|c|c|}
\hline Compound & $\Delta H_{\mathrm{sc}} / \mathrm{kJ} \mathrm{mol}^{-1}$ & $\Delta S_{\mathrm{sc}} / \mathrm{J} \mathrm{K}^{-1} \mathrm{~mol}^{-1}$ & $T_{\mathrm{C}}{ }^{a} / \mathrm{K}$ & $R^{b} / \AA ̊$ & Ref. \\
\hline$\left[\mathrm{LaFe}\left(\mathrm{L}^{1}\right)_{3}\right]^{5+}$ & $20.6(6)$ & $57(3)$ & $361(8)$ & 1.216 & 31 \\
\hline$\left[\mathrm{SmFe}\left(\mathrm{L}^{1}\right)_{3}\right]^{5+}$ & $20.0(9)$ & $55(4)$ & $364(8)$ & 1.132 & 31 \\
\hline$\left[\mathrm{LaFe}\left(\mathrm{L}^{2}\right)_{3}\right]^{5+c}$ & $30.0(2)$ & $88(1)$ & $339(5)$ & 1.216 & 36,38 \\
\hline$\left[\mathrm{YFe}\left(\mathrm{L}^{2}\right)_{3}\right]^{5+c}$ & $29.8(3)$ & $86(1)$ & $345(5)$ & 1.075 & 36,38 \\
\hline$\left[\mathrm{LuFe}\left(\mathrm{L}^{2}\right)_{3}\right]^{5+c}$ & $28.9(4)$ & $82(2)$ & $353(4)$ & 1.032 & 36,38 \\
\hline$\left[\mathrm{LaFe}\left(\mathrm{L}^{4}\right)_{3}\right]^{5+}$ & $30.1(2)$ & $94(1)$ & $320(5)$ & 1.216 & 36 \\
\hline$\left[\mathrm{YFe}\left(\mathrm{L}^{4}\right)_{3}\right]^{5+}$ & $29.2(2)$ & $89(1)$ & $327(4)$ & 1.075 & 36 \\
\hline$\left[\mathrm{LuFe}\left(\mathrm{L}^{4}\right)_{3}\right]^{5+}$ & $28.8(2)$ & $87(1)$ & $331(3)$ & 1.032 & 36 \\
\hline
\end{tabular}

${ }^{a}$ Critical temperature for which $x_{\mathrm{hs}}=0.5\left(T_{\mathrm{C}}=\Delta H_{\mathrm{sc}} / \Delta S_{\mathrm{sc}}\right) .{ }^{b}$ Effective ionic radius for nine-co-ordinate $\mathrm{Ln}^{\mathrm{III}} .{ }^{51}{ }^{c} \Delta H_{\mathrm{sc}}$ and $\Delta S_{\mathrm{sc}}$ of $(\mathrm{HHH})-$ $\left[\mathrm{LnFe}\left(\mathrm{L}^{2}\right)_{3}\right]^{\mathrm{s}}$ were obtained by non-linear least-squares fits (ref. 36) of the original data (ref. 38) and are thus slightly different from those previously obtained by linear least-squares fitting processes. ${ }^{36,38}$

sulfonamide group and (ii) a concomitant destabilisation of the iron(III) state for $\mathrm{L}^{4}$ (also three orders of magnitude in the formation constants) resulting from the electron-withdrawing $\sigma$ character of this group. ${ }^{36}$ Taking into account the Hammett constant $\left(\sigma_{\mathrm{m}}=0.51\right.$ for $\mathrm{R}=\mathrm{SO}_{2} \mathrm{NMe}_{2}$ and 0.30 for $\left.\mathrm{R}=\mathrm{SO}_{3}{ }^{-}\right)$, we can reasonably expect similar behaviour for $\mathrm{L}^{5}$ in water.

\section{Conclusion}

Judicious programming and matching of the components (i.e. the segmental ligand and the metal ions) provide self-assembly processes which are selective enough to allow the preparation and isolation of well defined heterodimetallic $\mathrm{d}-\mathrm{f}$ complexes. For a given d-block ion $(\mathrm{M}=\mathrm{Fe}, \mathrm{Co}$ or $\mathrm{Zn})$, the triple-stranded helicates $(\mathrm{HHH})-\left[\operatorname{LnM}\left(\mathrm{L}^{i}\right)_{3}\right]^{5+}(\mathrm{i}=2$ or 4$)$ can be obtained for all lanthanides and paramagnetic NMR analyses in solution demonstrate the existence of the same structure along the complete series consistent with a nine-co-ordinate metallic cavity which can accommodate lanthanides of different sizes according to the Induced fit concept. ${ }^{1,49}$ The considerable intramolecular intermetallic distances in $(\mathrm{HHH})-\left[\operatorname{LnM}\left(\mathrm{L}^{i}\right)_{3}\right]^{5+}(c a .9$ $\AA$ A) prevent strong magnetic and/or electronic coupling between the metal ions and through-space interactions (multipolar energy transfers) and/or subtle mechanical couplings (tunable iron(II) spin crossover) can be detected and investigated for isolated $\mathrm{d}-\mathrm{f}$ pairs. Moreover, the receptors can specifically be modified in order finely to tune the structural and electronic properties of one particular site thus leading to the partial programming of the properties of the second metal. As a first step toward this goal, $\mathrm{L}^{4}$ demonstrates that electronic properties of the pseudo-octahedral d-block complex can significantly be modified without affecting (i) the assembly process and (ii) the electronic characteristics of the neighbouring lanthanide site. The use of complicated multi-component self-assembly processes to prepare the final heterodimetallic complexes is a limiting factor because the selection of one particular complex within the 'dynamic virtual library' requires detailed and complete characterisation of the thermodynamic equilibria. The systematic combination of ES-MS, spectrophotometry, potentiometry and crystal-field independent paramagnetic NMR may overcome this limitation in favourable cases when the d-block ion is either a diamagnetic (low spin $\mathrm{Fe}^{\mathrm{II}}$, low spin $\mathrm{Co}^{\mathrm{III}}, \mathrm{Zn}^{\mathrm{II}}$ ) or a fast-relaxing paramagnetic ion $\left(\mathrm{Co}^{\mathrm{II}}\right.$, high spin $\left.\mathrm{Fe}^{\mathrm{II}}\right)$. With this restriction in mind, luminescent probes $(\mathrm{HHH})-\left[\mathrm{LnZn}\left(\mathrm{L}^{i}\right)_{3}\right]^{5+}$ $(i=2$ or 4$)$ and $(\mathrm{HHH})-\left[\operatorname{LnZn}\left(\mathrm{L}^{3}-\mathrm{H}\right)_{3}\right]^{2+}(\mathrm{Ln}=\mathrm{Eu}$ or $\mathrm{Tb})$, tunable thermally addressed spin-crossover switches (HHH)$\left[\operatorname{LnFe}\left(\mathrm{L}^{i}\right)_{3}\right]^{5+}(i=1,2$ or 4$)$ and electrochemically triggered podates $(\mathrm{HHH})-\left[\mathrm{LnCo}\left(\mathrm{L}^{2}\right)_{3}\right]^{5+/ 6+}$ have been designed for their unusual properties resulting from synergetic effects in weakly coupled heterodimetallic edifices. As suggested by the abrupt destabilisation of the complexes $(\mathrm{HHH})-\left[\operatorname{LnFe}\left(\mathrm{L}^{1}\right)_{3}\right]^{5+}$ for small $\mathrm{Ln}^{\mathrm{III}}$ which can be assigned to repulsive intramolecular interstrand interactions, ${ }^{50}$ subtle structural effects and selectivity can be implemented via secondary non-covalent inter- actions. In this context, the introduction of dynamically inert and stereochemically demanding $\mathrm{Cr}^{\mathrm{III}}$ in the d-block tripod of $(\mathrm{HHH})-\left[\operatorname{LnCr}\left(\mathrm{L}^{i}\right)_{3}\right]^{6+}$ remains a challenge which should open fascinating perspectives for (i) the design of supramolecular directional light-converting devices and (ii) the syntheses of preorganised facial nine-co-ordinate receptors for $\mathrm{Ln}^{\text {III }}$.

\section{Acknowledgements}

This work is supported through grants from the Swiss National Science Foundation.

\section{References}

1 J.-P. Costes, F. Dahan, A. Dupuis, S. Lagrave and J.-P. Laurent, Inorg. Chem., 1998, 37, 153; C. Piguet and J.-C. G. Bünzli, Chem. Soc. Rev. 1999, 28, 347 and references therein.

2 P. Guerriero, S. Tamburini and P. A. Vigato, Coord. Chem. Rev., 1995, 139, 17 and references therein; N. Brianese, U. Casellato, S. Tamburini, P. Tomasin and P. A. Vigato, Inorg. Chim. Acta, 1998, 272, 235; J. Lisowski and P. Starynowicz, Inorg. Chem., 1999, 38, 1351.

3 O. Kahn, Adv. Inorg. Chem., 1995, 43, 179 and references therein; M. Andruh, I. Ramade, E. Codjovi, O. Guillou, O. Kahn and J.-C. Trombe, J. Am. Chem. Soc., 1993, 115, 1822; I. Ramade, O. Kahn, Y. Jeannin and F. Robert, Inorg. Chem., 1997, 36, 930 .

4 C. Benelli, A. C. Fabretti and A. Giusti, J. Chem. Soc., Dalton Trans., 1993, 409; M. Sakamoto, M. Hashimura, K. Matsuki, N. Matsumoto, K. Inoue and H. Ottawa, Bull. Chem. Soc. Jpn., 1991, 64, 3639; C. Bennelli, A. Caneshi, D. Gatteschi, O. Guillou and L. Pardi, Inorg. Chem., 1990, 29, 1750.

5 J.-P. Costes, F. Dahan, A. Dupuis and J.-P. Laurent, Inorg. Chem., 1996, 35, 2400; J.-P. Costes, F. Dahan, A. Dupuis and J.-P. Laurent, Inorg. Chem., 1997, 36, 3429; J.-P. Costes, F. Dahan, A. Dupuis and J.-P. Laurent, Chem. Eur. J., 1998, 4, 1616; J.-P. Costes, F. Dahan and A. Dupuis, Inorg. Chem. 2000, 39, 165.

6 J.-P. Costes, F. Dahan, A. Dupuis and J.-P. Laurent, Inorg. Chem., 2000, 39, 169 .

7 M. L. Kahn, C. Mathonière and O. Kahn, Inorg. Chem., 1999, 38, 3692.

8 S. J. Archibald, A. J. Blake, S. Parsons, M. Schröder and R. E. P. Winpenny, J. Chem. Soc., Dalton Trans., 1997, 173; E. K. Brechin, S. G. Harris, S. Parsons and R. E. P. Winpenny, J. Chem. Soc., Dalton Trans., 1997, 1665.

9 J.-M. Lehn, Supramolecular Chemistry, VCH, Weinheim, New York, Basel, Cambridge, Tokyo, 1995; C. Piguet, J. Incl. Phen. Macrocycl. Chem., 1999, 34, 361.

10 S. Decurtins, M. Gross, H. W. Schmalle and S. Ferlay, Inorg. Chem., $1998,37,2443$.

11 A. J. Stemmler, J. W. Kampf, M. L. Kirk, B. H. Atasi and V. L. Pecoraro, Inorg. Chem., 1999, 38, 2807.

12 X. Zhang, Y. Cui, F. Zheng and J. Huang, Chem. Lett., 1999, 1111.

13 J. B. Goodenough, Magnetism and Chemical Bonding, Interscience, New York, 1963.

14 Z. Xu, P. W. Read, D. E. Hibbs, M. B. Hursthouse, K. M. A. Malik, B. O. Patrick, S. J. Rettig, M. Seid, D. A. Summers, M. Pink, R. C. Thompson and C. Orvig, Inorg. Chem., 2000, 39, 508; R. W. Saalfrank, V. Seitz, D. L. Caulder, K. N. Raymond, M. Teichert and D. Stalke, Eur. J. Inorg. Chem., 1998, 1313. 
15 T. Sanada, T. Suzuki and S. Kaizaki, J. Chem. Soc., Dalton Trans., 1998, 959.

16 F. S. Richardson, Chem. Rev., 1982, 82, 541; W. W. Horrocks and D. R. Sudnick, Acc. Chem. Res., 1981, 14, 384.

17 C. F. Meares, S. M. Yeh and L. Stryer, J. Am. Chem. Soc., 1981, 103, 1607; W. W. Horrocks, B. Holmquist and B. L. Vallee, Proc. Natl. Acad. Sci. U.S.A., 1975, 72, 4764; C. K. Luk, Biochemistry, 1971, 10, 2838; E. T. O’Keeffe, R. L. Hill and J. E. Bell, Biochemistry, 1980, 19, 4954.

18 D. H. Metcalf, S. W. Snyder, J. N. Demas and F. S. Richardson, J. Am. Chem. Soc., 1990, 112, 5681; D. H. Metcalf, J. M. McD. Stewart, S. W. Snyder, C. M. Grisham and F. S. Richardson, Inorg. Chem., 1992, 31, 2445; J. P. Bolender, D. H. Metcalf and F. S. Richardson, Chem. Phys. Lett., 1993, 213, 131; R. B. Rexwinkel, S. C. J. Meskers, J. P. Riehl and H. P. J. M. Dekkers, J. Phys. Chem., 1993, 97, 3875; C. L. Maupin, S. C. J. Meskers, H. P. J. M. Dekkers and J. P. Riehl, Chem. Commun., 1996, 2487.

19 P. A. Brayshaw, J.-C. G. Bünzli, P. Froidevaux, J. M. Harrowfield, Y. Kim and A. N. Sobolev, Inorg. Chem., 1995, 34, 2068.

20 C. Piguet, G. Bernardinelli and G. Hopfgartner, Chem. Rev., 1997, 97, 2005 and references therein.

21 A. M. Garcia, F. J. Romero-Salguero, D. Bassani, J.-M. Lehn, G. Baum and D. Fenske, Chem. Eur. J., 1999, 5, 1803 and references therein.

22 F. M. Raymo and J. F. Stoddart, Curr. Opinion Colloid Interface Sci., 1998, 3, 150 and references therein.

23 G. A. Breault, C. A. Hunter and P. C. Mayers, Tetrahedron, 1999 55, 5265; F. M. Raymo and J. F. Stoddart, Chem. Rev., 1999, 99 1643.

24 V. L. Pecoraro, A. J. Stemmler, B. R. Gibney, J. L. Bodwin, H. Wang, J. W. Kampf and A. Barwinski, Prog. Inorg. Chem., 1997, 45, 83 .

25 D. L. Caulder and K. N. Raymond, J. Chem. Soc., Dalton Trans., 1999, 1185; D. L. Caulder and K. N. Raymond, Acc. Chem. Res. 1999, 32, 975.

26 R. C. Scarrow, D. L. White and K. N. Raymond, J. Am. Chem. Soc., 1985, 107, 6540; C. Piguet, G. Bernardinelli, B. Bocquet, A Quattropani and A. F. Williams, J. Am. Chem. Soc., 1992, 114, 7440.

27 (a) C. Piguet, J.-C. G. Bünzli, G. Bernardinelli, G. Hopfgartner and A. F. Williams, J. Am. Chem. Soc., 1993, 115, 8197; (b) N. Martin, J.-C. G. Bünzli, V. McKee, C. Piguet and G. Hopfgartner, Inorg. Chem., 1998, 37, 577; (c) M. Elhabiri, R. Scopelliti, J.-C. G. Bünzli and C. Piguet, J. Am. Chem. Soc., 1999, 121, 10747.
28 C. Piguet, G. Hopfgartner, B. Bocquet, O. Schaad and A. F. Williams, J. Am. Chem. Soc., 1994, 116, 9092.

29 C. Piguet, E. Rivara-Minten, G. Hopfgartner and J.-C. G. Bünzli, Helv. Chim. Acta, 1995, 78, 1541.

30 J.-M. Lehn, Chem. Eur. J., 1999, 5, 2455 and references therein.

31 C. Piguet, E. Rivara-Minten, G. Hopfgartner and J.-C. G. Bünzli, Helv. Chim. Acta, 1995, 78, 1651.

32 C. Piguet, J.-C. G. Bünzli, G. Bernardinelli, G. Hopfgartner, S. Petoud and O. Schaad, J. Am. Chem. Soc., 1996, 118, 6681.

33 A. F. Williams, C. Piguet and R. Carina, Transition Metals Supramolecular Chem., 1994, 448, 409; A. F. Williams, R. F. Carina, L. Charbonnière, P. G. Desmartin and C. Piguet, NATO AST Ser. Phys. Supramolecular Chem., 1996, 379; J. S. Lindsey, New J. Chem., 1991, 15, 153

34 S. Rigault, C. Piguet, G. Bernardinelli and G. Hopfgartner, Angew. Chem., Int. Ed., 1998, 37, 169.

35 C. Edder, C. Piguet, J.-C. G. Bünzli and G. Hopfgartner, J. Chem. Soc., Dalton Trans., 1997, 4657.

36 C. Edder, C. Piguet, G. Bernardinelli, C. G. Bochet, J. Mareda, J.-C. G. Bünzli and G. Hopfgartner, Inorg. Chem., in press.

37 C. Piguet, Chimia, 1996, 50, 144.

38 C. Piguet, E. Rivara-Minten, G. Bernardinelli, J.-C. G. Bünzli and G. Hopfgartner, J. Chem. Soc., Dalton Trans., 1997, 421.

39 S. Rigault, C. Piguet and J.-C. G. Bünzli, J. Chem. Soc., Dalton Trans., 2000, 2045.

40 R. M. Golding and M. P. Halton, Aust. J. Chem., 1972, 25, 2577.

41 B. Bleaney, J. Magn. Reson., 1972, 8, 91.

42 J. A. Peters, J. Huskens and D. J. Raber, Prog. Nucl. Magn. Reson. Spectrosc., 1996, 28, 283; J. A. Peters, J. Magn. Reson., 1986, 68, 240.

43 C. Platas, F. Avecilla, A. de Blas, C. F. G. C. Geraldes, T. RodriguezBlas, H. Adams and J. Mahia, Inorg. Chem., 1999, 38, 3190.

44 S. Rigault and C. Piguet, J. Am. Chem. Soc., in press.

45 S. Rigault and C. Piguet, unpublished results.

46 S. Petoud, J.-C. G. Bünzli, C. Piguet, Q. Xiang and R. Thummel, J. Luminesc., 1999, 82, 69.

47 C. Piguet, A. F. Williams, G. Bernardinelli, E. Moret and J.-C. G. Bünzli, Helv. Chim. Acta, 1992, 75, 1697.

48 C. Platas Iglesias, M. Elhabiri, M. Hollenstein, J.-C. G. Bünzli and C. Piguet, J. Chem. Soc., Dalton Trans., 2000, 2031.

49 D. E. Koshland, Angew. Chem., Int. Ed. Engl., 1994, 33, 2375 and references therein; S. J. Rowan, D. G. Hamilton, P. A. Brady and J. K. M. Sanders, J. Am. Chem. Soc., 1997, 119, 2578.

50 S. Petoud, J-C. G. Bünzli, F. Renaud, C. Piguet, K. J. Schenk and G. Hopfgartner, Inorg. Chem., 1997, 36, 5750.

51 R. D. Shannon, Acta Crystallogr., Sect. A, 1976, 32, 751. 